\title{
Evaluating the experience of using e-learning tools in tourism education during COVID-19: students' perspectives
}

Marwa. A.M. Abdel-Jalil*

Faculty of Tourism and Hotels, Fayoum University, Egypt

\section{ARTICLE INFO}

Keywords:

E-learning

Tourism and Hospitality

Education

COVID-19

Egypt

\begin{abstract}
E-learning has become one of the most appropriate ways to deliver curricula, conduct assessments and do exams, especially after the spread of Coronavirus (COVID-19) pandemic, which is a major turning point in accelerating the use of e-learning technologies around the world. This study evaluates the experience and readiness of tourism undergraduate students for adopting e-learning in governmental universities of Egypt. The study employs the deductive approach using quantitative method and uses a questionnaire form to evaluate internet efficacy, communication self-efficacy, computer anxiety and institutional support relevant to student's readiness of e-learning. Collecting data from a random sample of 1757 students, the findings revealed positive attitudes of students toward e-learning experience. The present study provides useful implications to policy-makers in tourism and hospitality education in Egypt and other developing countries in order to develop the e-learning experience.
\end{abstract}

C2020 Faculty of Tourism and Hotels, Fayoum University All rights reserved

\section{Introduction}

With the declaration of the COVID-19 pandemic at the end of 2019 and its global outbreak, working conditions have been changed and caused many disruptions in the countries' economies (Dinh \& Nguyen, 2020; Shahzad, et al., 2020). According to World Health Organization there are 172,680,104 confirmed COVID-19 positive cases in the world, with 3,711,794 confirmed deaths, 155,411,521 recovered and the virus has affected 222 countries. To confront the pandemic, the majority of world countries have been keen of the necessity to implement social distancing (Dinh \& Nguyen, 2020), as the Egyptian Ministry of Higher Education and the Supreme Council of Egyptian Universities mandated the closure of all educational institutions as an emergency measure to decrease the spread of infection with the need to delegate all educational activities to e-learning (Ministry of Higher Education \& Scientific Research, 2021). Some Tourism and Hotel faculties in the Egyptian universities offered supplementary electronic services to the educational process such as students e-mails, blogs, in addition to providing students with uploaded materials, and broadcasting recorded lectures through the Internet (Hammad \& Zohry, 2020).

E-learning is not a recent phenomenon (Ismaili, 2021), it has appared since the mid-1990s (Masrom, et al., 2008; Ozturk, et al., 2018; Ismaili, 2021), as a result of technological advancement and the spread of information and communication technology (ICT) applications, which prompted many universities and educational institutions to use it to support and

\footnotetext{
${ }^{*}$ Contact Marwa. A.M. Abdel-Jalil at: mam32@ fayoum.edu.eg
} 
facilitate the educational process (Ozturk, et al., 2018; Hammad \& Zohry, 2020). However, it should be noted that at the moment e-learning in Egypt is still in its nascent (Mukhtar, et al., 2020). Thus, e-learning developers and providers need more understanding of how students' realize and interact of the e-learning elements as perception of students and their attitudes are critical to stimulate and learn along with how to apply these methods more efficiently to enhance learning process (Smart \& Cappel, 2006). E-learning is an abbreviation term of electronic learning, which also commonly known as distributed learning, hybrid learning, web-based learning, Open learning, online learning, and internet-based learning (e.g, Aldhafeeri, 2016; Forson \& Vuopala, 2019; Alqahtani \& Rajkhan, 2020; Hammad \& Zohry, 2020).

Thus, e-learning has many definitions in different contexts. As stated by Aldhafeeri and Khan (2016, p. 203), e-learning can be "an innovative approach for delivering well-designed, learner-centered, interactive, and facilitated learning environments to anyone, anyplace, anytime by utilizing the attributes and resources of various digital technologies along with other forms of learning materials suited for the open and distributed learning environment". In addation, Gurley (2018, p.200) mentioned that elearning is "education that uses one or more technologies to deliver instructions to students who are separated from the instructor and to support regular and substantive interaction between the students and the instructor synchronously or asynchronously". (Forson \& Vuopala, 2019, p. 277) Forson and Vuopala (2019, p. 277) also defined e-learning as "provision of instructions via digital devices such as a computer or mobile device that is thought of to support learning". Meanwhile Alqahtani and Rajkhan (2020, p.2) defined e-learning as "the wide set of applications and processes which use available electronic media and tools to deliver vocational education and training". Accordingly, E-learning where the learner is at a distance from the lecturer, uses some forms of technology to access educational materials, interact with the lecturer and other peers, and a sort of support is provided to the learners (Rapanta, et al., 2020; Ismaili, 2021). In addition, self-speed independent study units and simultaneous or nonsynchronous interactive lectures can be used (Smart \& Cappel, 2006).

Educational institutions and students have hurried to use e-learning because there are many advantages that can turn education into a lifelong learning method, boost independent learning and promote learning efficacy (Hung \& Chou, 2015; Alqahtani \& Rajkhan, 2020; Khan, et al., 2020; Widodo, et al., 2020). Throught, The benefits of e-learning which include: flexibility as lecturs can be accessed at any time and anywhere as long as there is Internet connection (Bertea, 2009; Forson, et al. 2019), easy using of elearning platforms (Khan, et al., 2020), saving time and costs for students who move (Bertea, 2009), letting students to better recollect the information that is needed for traditional education, additionally educational institutions apply e-learning techniques to support communication between students and lecturers for a good exchange of knowledge. Furthermore it improves the learning community to accomplish personal goals (Alqahtani 2020). Despite the advantages of e-learning, it also has some possible drawbacks, for instance feelings of isolation and lack of human interaction with colleagues and lecturers, technology problems (Tuntirojanawong, 2013; Khan, et al., 2020), lack of basic computer skills and some students may suffer from phobias of utilizating computers and modern ICTs (Bertea, 2009; Tuntirojanawong, 2013; Rafique, et al., 2021), in addition to, the lack of self-regulation and selfstimulation. Moreover, problems arising from choosing the most suitable way to evaluante work participants in the e-learning process (Tuntirojanawong, 2013).

As a result of the imposition of quarantine, educational institutions have turned to e-learning instead of traditional learning in a very short period (Rafique, et al., 2021; Dinh \& Nguyen, 2020). UNESCO has explained that the transition to E-learning on a large scale as a very difficult and complex task for different education systems even in the best of circumstances, but it has become an urgent necessity (Ali, 2020). Hence, many developing countries have faced alot of challenges in transition process during the time of COVID-19, whether challenges for employees, students or administrators (Ali, 2020; Ismaili, 2021), For example, the readiness of instructors and institutional, experience coherence, gaps in student access and readiness, and confidence in institutions' ability to solve these problems (Fox, et al., 2020). While, Zhang, et al., (2020), and (Oyedotun, 2020) elucidated that the implementation of the e-learning policy faces at least five challenges, which are:

1- E-learning is limited by infrastructure in terms of how fast the internet is, internet providers are prepared for sudden huge demands for their services, and the differences in IT infrastructure between regions are substantial. 
2- Lack of ripe and disaggregated plans to switch to elearning in emergency times, causing uneven quality of lecturers and teaching resources used.

3- Inadequate pre-training on online educational requirements, whether for students, faculty members or staff.

4-The environment difference in teaching and learning between the university and the home, there may be a set of distraction factors from teaching and studying at home, whether through finding suitable spaces for learning, inadequate devices or an unstable network at home. Moreover, universities are a hub for social activity and human interaction without them the mental and physical health of students can be negatively affected.

5-The lack of clarity on what are the best teaching methods \& curricula, characteristics and patterns of E- learning, that can be used efficiently and effectively, and how teaching can be linked during and after the COVID-19 epidemic, as well as the need to take into account the unique features of Elearning and integrate them into daily teaching and learning.

Hence, this study aims to evaluate the experience and readiness of tourism undergraduate students for adopting e-learning in governmental universities of Egypt. The paper discusses the internet efficacy, communication self-efficacy, computer anxiety and institutional support relevant to student's readiness of e-learning. The study provides useful implications to policy-makers in tourism and hospitality education in Egypt and other developing countries in order to develop the e-learning experience

\section{Literature Review}

\subsection{Internet Self-efficacy}

Self-efficacy is defined as one's confidence in his ability to mobilize the motivation, cognitive resources, and the necessary action plans to perform potential tasks (Sam, et al., 2005; Galy \& Johnson, 2011). Understanding self-efficacy can contribute to the improvement and success of e-learning (Shen, et al., 2013). Since e-learning is based on the use of Internet networks, it is essential to know the abilities of students to complete Internet tasks and academic learning processes and to evaluate their competencies in the use of ICT (Hung, et al., 2010). Thus, the Internet self-efficacy (ISE) is not just about uploading or downloading files, but rather the individual's ability to perform high-level skills and work to discover errors and fix them easily. Besides , students with high ISE learn better than students with low ISE during e- learning, Accordingly ISE is considerd an important dimension that affects the extent of students' readiness for e-learning (Hung, 2016; Rafique, et al., 2021). Thus the first hypothesis is developped as follows:

\section{H1. Internet Self-efficacy has a significant effect on} Student readiness to E-learning

\subsection{Communication self-efficacy}

Communication self-efficacy (CSE) is parculiarly important in challenging learning environments, including the e-learning environment (Shen, et al., 2013), wherever personal beliefs and motivational circumstances can have an impact on performance (Alanazy, 2018), behavioral intent, and student readiness for e-learning (Ismaili, 2021; Rafique, et al., 2021). Hung, et al., (2010) and Rafique, et al., (2021) stated that shy students prefer interacting with other students in an e-learning environment more than in traditional learning environment. CSE in e-learning is a crucial dimension for transcending restrictions of online communication (Hung, 2016). Successful students should achieve the most benefit from online discussions (Rafique, et al., 2021). The using of async discussion is believed to be crucial for ideas and information exchanges, in addition to developing critical thinking and cooperation. Hence, it has become essential understand the best ways to communicate between students, their peers and lecturers during E-learning, , and how they are able to use computers and electronic communications effectivly (Hung, 2016; Hung, 2016 a). The more student's communication self-efficacy, interacts with lecturers, and contributes to the online community, the more likely to use active interaction strategies, such as writing, responding, and reflecting (Shen, et al., 2013). Therefore, the second hypothesis is developped:

H2. Communication self-efficacy has a positive effect on Student readiness to E-learning.

\subsection{Computer Anxiety}

Galy \& Johnson, (2011) indicated that computer anxiety (CA) as an individual's tendency to adverse reaction while considering using a computer or fear of using a computer. Computer anxiety is an emotional response, an emotional fear of possible negative outcomes such as damaging equipment or looking fool. Students with high computer anxiety may perform poorer than those with little or no computer anxiety. The higher the level of computer anxiety, the lesser they perform tasks, and computer skills they learn. However, although levels of Internet use may not affect computer self-efficacy, but high Internet use 
can reduce levels of computer anxiety among undergraduates. Undergraduate with less computer anxiety showed more positive attitudes toward the Internet (Sam, et al., 2005).The third hypothesis is formulated as follows:

\section{H3. Computer Anxiety has a negative effect on Student readiness to E-learning.}

\subsection{Institutional support}

The e-learning standard is an important issue that demands a basic focus. Nowadays, an unexpected turn has occurred from face-to-face learning to the Elearning (Shahzad, et al., 2020), which requires achieving quality of education, availability of skills, knowledge, experience and psychological preparedness for both students and lecturers (Forson \& Vuopala, 2019), furthermore the provision of excellent infrastructure like computers and modern IT equipment's (e.g., smart phones and devices, online learning platforms (software/mobile applications)) (Ali, 2020; Rafique, et al., 2021) Thus, Students must have accessibility to some of these to successfully participate in e-learning. In addition to the tendency of universities to change their education models using intellectual capital (Shahzad, et al., 2020).

Institutional support (IS) refers to active organizational encouragements in the form of pecuniary and nonpecuniary policies, rules and assistance that drive the employees to carry out their responsibilities in a highly efficient and productive manner (Falola, et al., 2020 ). IS corresponds to the factors that may assist or impede people's behavior in particular environments. Hung, (2016 a) analyzed educational environments and indicated that there are three significant types of institutional support; support for superiors, support for colleagues, and favourable organizational surroundings. In e-learning, the student is the main entity and the core of the educational system. The faculty staff responsibility is to study ways to maximize the possibility of students' environments to support learning and decrease the elements in the environments that may hinder it (Aldhafeeri \& Khan, 2016).

Therefore, to apply a learning-focused system, all stakeholders, counting university managers, faculty staff, support services staff, and the institution must be aware of the technology and institutional support factors based on students' perspectives that influence success in e-learning, , as well as be on the readiness to supply students with a purposeful learning environment supported by well-designed learning materials, Special when trying to adopt e-learning courses or programs (Masrom, et al., 2008; Aldhafeeri $\&$ Khan, 2016), Some of the institutional support that higher education institutions can provide includes: technical support, pedagogical support (Falola, et al., 2020 ), through training and support of faculty and students to make good use of e-learning technologies (Linjawi \& Agou, 2020), as well as the involvement of lecturers in the design of these courses (Philipsen, 2019). The fourth hypothesis is developed as follows:

H4. Institutional support has a significant effect on Student readiness to E-learning.

\subsection{Student readiness to e-learning and evaluation of e-learning experience in tourism education}

E-learning for students is a sort of education that includes motivation, communication competence, participation (Bertea, 2009). Warner, Christie, and Choy in 1998 outlined the first concept of e-learning readiness. They defined e-learning readiness as students' preference for classroom instructional process versus face-to-face learning, in addition to students' trust in using various types of technology, world wide web, particularly tools that rely on the computer for communicating in online learning, and students' participation in independent learning (Rafique, et al., 2021). Furthermore, Demir, (2015) refere that eLearning readiness as the ability of stakeholders to use e-learning resource and multimedia technologies and take advantage of their benefits in order to enhance the quality of learning.

Based on Aldhafeeri \& Khan (2016) E-learning readiness is an appraisal of some organizational and individual factors that must be deemed if institutions want to succeed in the introduction of an e-learning strategy. Where e-learning strategies demand a great deal of up-front analysis, time for developing, money, technology infrastructure, prior experience with technology, self-efficacy, and leadership support to succeed (Aldhafeeri \& Khan, 2016; Rafique, et al., 2021). Demir, (2015) explained that e-Learning readiness is one of the most important factors affecting the successful outcomes of e-learning programmes. The majority of students have their own devices that support internet as computers or mobile phones for connecting to formal and informal networking platforms such emails, blogging, etc (Khan, et al., 2020), the ability to form a virtual study group with other and the comfortable with doing various Internet tasks that may include navigating the web, emailing, downloading and uploading files, and ect (Tuntirojanawong, 2013). 
Hammad \& Zohry, (2020) claried that in the tourism education, when faculty staff merge network technology into their tradational education well, this leads to the formation of a positive attitude by students towards e-learning, and improves their sense of satisfaction, comfort and flexibility. This achieves the best integration between the two methods of education and better results than only traditional educational courses. The fifth hypothesis is formulated as follows:

H5. Student readiness to E-learning has a significant effect on evaluation of e-learning experience in tourism education

\subsection{Conceptual framework and Hypotheses} development

Fig 1

Research framework and hypotheses development

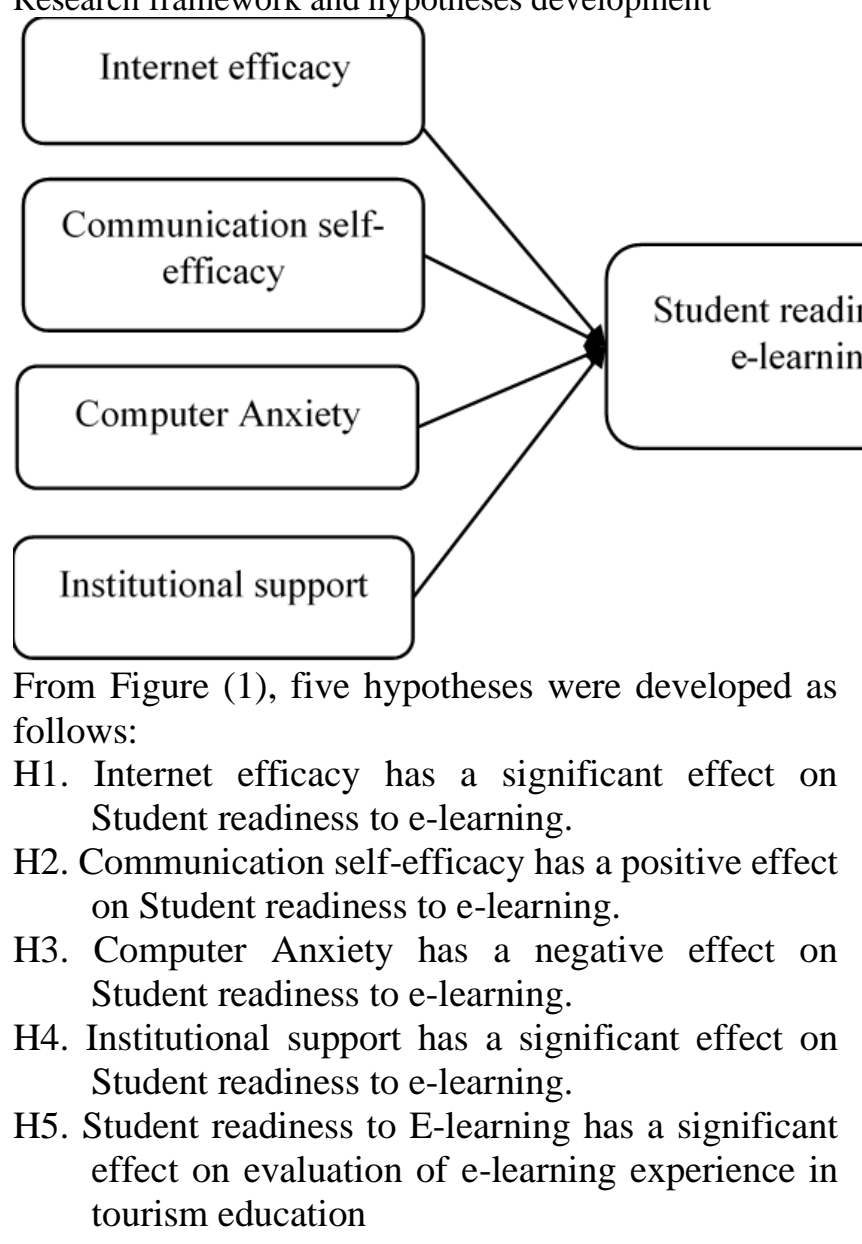

\section{Methodology}

\subsection{Research Instrument}

The deductive approach employing quantitative method to test the hypothesized model. There are six constructs in the proposed research model (Figure1): Internet efficacy, communication self-efficacy,
Based on the literature review of student readiness to e-learning and using of E-learning tools in tourism education at faculties of tourism and hotels in Egyptian universities (Helwan, Alexandria, Fayoum, Suze Canal, Minia, Sadat City, Mansoura, Bani Sweif, and Luxor), the conceptual framework of the current study has been developed. It has four predictors of student readiness to e-learning. These are communication self-efficacy, institutional support, Internet efficacy and computer anxiety. These four constructs act as predictors to measure their impact on student readiness to E-learning and how this readiness affect students' evaluation of e-learning experience (Figure 1). 
age university, department, year of study, technology skills level, living area and e-learning platform(s) used). The second section consisted of the measurement scales for the studied constructs, selected depending on existing validated scales or adapted from the previous literature (Table1). From the 29 items, the questionnaire form included three items to measure communication self-efficacy, six Table 1: items for institutional support, five items for Internet efficacy, four items to measure computer anxiety. In addition, five items to measure student readiness to elearning. Moreover, six items for evaluation of elearning experience in tourism education. The indicators were slightly modified to be appropriate for the present study.

Research Constructs

\begin{tabular}{|c|c|c|c|}
\hline Construct & Measure & $\begin{array}{l}\text { No. of } \\
\text { Items }\end{array}$ & Adopted from \\
\hline & Internet efficacy & & \\
\hline IE1 & $\begin{array}{l}\text { I can deal with various computer programs such as } \\
\text { Microsoft Office and Adobe Acrobat }\end{array}$ & \multirow[t]{5}{*}{05} & Hung, (2010) \\
\hline IE2 & I can work in a group for studies online. & & Rafique, et al., (2020) \\
\hline IE3 & $\begin{array}{l}\text { I am able to perform homework and online educational } \\
\text { activities (participate in classroom forums - download } \\
\text { assignments...etc) }\end{array}$ & & Hung, (2010) \\
\hline IE4 & $\begin{array}{l}\text { I can interact quickly and efficiently with e-learning } \\
\text { techniques }\end{array}$ & & Hung, (2016) ; Hung, (2016 a) \\
\hline \multirow[t]{2}{*}{ IE5 } & E-learning platforms are easy to use. & & Khan., et al. (2020) \\
\hline & Communication self-efficacy (CSE) & & \\
\hline CS1 & $\begin{array}{l}\text { I trust in myself when utilizing e-learning tools to efficiently } \\
\text { connect with others. }\end{array}$ & \multirow[t]{3}{*}{03} & Hung, (2016) \\
\hline $\mathrm{CS} 2$ & I trust in myself when handling with e-learning content well & & Shen, et al., (2013) \\
\hline \multirow[t]{2}{*}{ CS3 } & I trust in myself when usage e-learning system. & & Shen, et al., (2013) \\
\hline & Computer Anxiety & & \\
\hline CA1 & I feel nervous when using the computer technologies & \multirow[t]{4}{*}{04} & Bertea, (2009) \\
\hline CA2 & $\begin{array}{l}\text { I am afraid that I will make mistakes that I'm not able to } \\
\text { correct }\end{array}$ & & $\begin{array}{l}\text { Hung, (2016); Rafique, et al., } \\
(2020) \text {. }\end{array}$ \\
\hline CA3 & $\begin{array}{l}\text { I find difficulty to understand the technical characteristics } \\
\text { of computers for e-learning systems }\end{array}$ & & Ali, $(2020)$ \\
\hline \multirow[t]{2}{*}{ CA4 } & I don't like working with technologies smarter than me & & Bertea, (2009) \\
\hline & Institutional support (IS) & & \\
\hline IS1 & My faculty has an efficient e-learning platform & \multirow[t]{6}{*}{06} & Ali, (2020); Rafique, et al., (2020) \\
\hline IS2 & $\begin{array}{l}\text { In my faculty, IT technical support employees are available } \\
\text { to aid professors and students with e-learning techniques }\end{array}$ & & $\begin{array}{l}\text { Masrom, (2008) Aldhafeeri., et al. } \\
(2016)\end{array}$ \\
\hline IS3 & In my faculty, constant internet computers are available. & & Ali, (2020); Rafique, et al., (2020) \\
\hline IS4 & $\begin{array}{l}\text { My faculty is given considerable attention to encourage } \\
\text { faculty members to switch from face-to-face learning to } \\
\text { online learning }\end{array}$ & & Shahzad, et al., (2020) \\
\hline IS5 & $\begin{array}{l}\text { My faculty hold workshops and training courses to qualify } \\
\text { students to use e-learning techniques }\end{array}$ & & Linjawi \& Agou, (2020) \\
\hline \multirow[t]{2}{*}{ IS6 } & $\begin{array}{l}\text { My faculty encourages students to use e-learning } \\
\text { technologies in lectures }\end{array}$ & & Linjawi \& Agou, (2020) \\
\hline & Student readiness & & \\
\hline SR1 & $\begin{array}{l}\text { In home, I have a computer /smart phone connected to the } \\
\text { internet }\end{array}$ & \multirow[t]{4}{*}{05} & Khan, et al., (2020) \\
\hline SR2 & I have an active university e-mail address & & Hammad \& Zohry, (2020) \\
\hline SR3 & $\begin{array}{l}\text { I have a suitable environment at home that enables me to } \\
\text { attend lectures online without distraction }\end{array}$ & & Zhang, et al., (2020) \\
\hline SR4 & $\begin{array}{l}\text { I have internet service that enables me to attend online } \\
\text { lectures, download assignments and research }\end{array}$ & & Hammad \& Zohry, (2020) \\
\hline
\end{tabular}




\begin{tabular}{|c|c|c|c|}
\hline SR5 & $\begin{array}{l}\text { I can work in virtual groups and perform e-learning } \\
\text { activities with my colleagues }\end{array}$ & & Tuntirojanawong, S. (2013) \\
\hline & Evaluation of e-learning experience & & \\
\hline ET1 & Study through e-learning is characterized by flexibility & 06 & $\begin{array}{l}\text { Forson, et al. (2019) \& Bertea, } \\
(2009)\end{array}$ \\
\hline ET2 & $\begin{array}{l}\text { Various e-learning tools help to achieve interactive } \\
\text { communication between the student and the lecturer }\end{array}$ & & $\begin{array}{l}\text { Alqahtani (2020); Khan., et al. } \\
(2020)\end{array}$ \\
\hline ET3 & $\begin{array}{l}\text { E-learning helps me to record lectures and return to them at } \\
\text { any time }\end{array}$ & & $\begin{array}{l}\text { Hammad \& Zohry, (2020); } \\
\text { Aldhafeeri \& Khan, (2016) }\end{array}$ \\
\hline ET4 & $\begin{array}{l}\text { E-learning provides me more incentives than traditional } \\
\text { lectures }\end{array}$ & & Aldhafeeri \& Khan, (2016) \\
\hline ET5 & $\begin{array}{l}\text { I prefer to continue the e-learning experience in the future } \\
\text { as an alternative to traditional learning }\end{array}$ & & Hammad \& Zohry, (2020) \\
\hline ET6 & $\begin{array}{l}\text { I feel satisfied about the e-learning technologies that have } \\
\text { been used in my college in the past period }\end{array}$ & & Hammad \& Zohry, (2020) \\
\hline
\end{tabular}

\subsection{Research population and sample}

The population of the study included relevant students in Egyptian faculties of tourism and hotels including (Helwan, Alexandria, Fayoum, Suze Canal, Minia, Sadat City, Mansoura, Bani Sweif, and Luxor). A random sample was employed to select relevant students. Of 1834 responses, 1757 valid questionnaires were collected. Data were collected, coded, and entered in SPSS 16 for statistical analysis. Descriptive statistics were computed including frequencies, percentages, mean, and standard deviation. To test the research hypotheses, structural equation modelling, the advanced multivariate technique was used using WarpPLS software.

\section{Research Findings}

\subsection{Descriptive statistics}

The descriptive statistics show that $47.4 \%$ of the respondents are male, whereas $52.6 \%$ are female. $2.0 \%$ of respondents are less than 18 years, while $71.4 \%$ of them is between 19 and 21 years old, and $26.6 \%$ is aged more than 21 years.

Moreover, $26.8 \%$ of the respondents belong to Helwan University, $17.8 \%$ to Luxor University, $15.2 \%$ to Bani Sweif University, $13.8 \%$ to Sadat City University, $12.1 \%$ to Fayoum University, $6.7 \%$ to Suez Canal University, $4.7 \%$ to Alexandria University, $1.7 \%$ to Minya University, and 1.3\% Mansoura University. In addition, $52.0 \%$ of the responders belong to Tourism Studies Department, 28.4\% Hotel Studies Department, and $19.6 \%$ Tourist Guidance Department. $36.7 \%$ of respondents is in the first year, $30.9 \%$ is the second year, $19.6 \%$ is the third year and $12.8 \%$ is the fourth year.

Besides, $50.1 \%$ of the respondents are classified skillful in using technology, $42.7 \%$ is beginners and
7.2\% have expert technology skills level. $72.4 \%$ of respondents are living in urban area, and $27.6 \%$ in rural area. Furthermore, $57.3 \%$ of the respondents are using Zoom e-learning program in their faculties, $56.7 \%$ of them are using Microsoft Teams, $7.9 \%$ of them are using Google Meet, $2.4 \%$ of them are using Edmodo, $1.4 \%$ of them are using Blackboard platform, and $10.8 \%$ are using other platforms such as, Google Classroom, Discord, Skype, WhatsApp, Facebook Live, Telegram Groups, and Clubhouse.

Means and standard deviations of responses for the measured constructs are provided in table (2). The mean values of responses for all constructs range from agree (3.5) on student readiness to e-learning to neutral (2.7) on computer anxiety. Respondents' opinions towards student readiness to e-learning (mean $=3.5$, agree), Internet efficacy (mean $=3.3$, neutral), communication self-efficacy (mean $=3.2$, neutral), use of e-learning tools (mean $=3.05$, neutral), institutional support (mean $=2.8$, neutral), and computer anxiety (mean $=2.7$, neutral).

\subsection{Measurement Model}

Table 2 shows the standardized loadings of indicators, Cronbach's alpha (CA), composite reliability (CR), Average Variance Extracted (AVE) of constructs and Square Root of AVEs. The coefficient of internal consistency of scale reliability (Cronbach's alpha) and the composite reliability $(\mathrm{CR})$ values were greater than 7 for all constructs. Thus, the internal consistency of the constructs used in this study is evident. Additionally, each construct's AVE is larger than 0.5 which leads to the existence of convergent validity. On the other hand, discriminant validity was investigated by comparing the square roots of the AVE for each construct with the correlations and it was greater than correlations among constructs which is evidence of 
discriminant validity. The model fit indices for measurement model are within target limits: average path coefficient $=0.291 \mathrm{p}<.001$; average $\mathrm{R} 2=.489$, $\mathrm{p}$ $<.001$; average adjusted R2 $=.488, \mathrm{p}<.001$; average block variance inflation factor $=1.979$; average full

Table 2

The Measurement Model

\begin{tabular}{|c|c|c|c|c|c|c|}
\hline Construct & Indicator & Standardized Loading & Cronbach's Alpha $(\propto)$ & CA ( $(\rho)$ & AVE & SqR AVE \\
\hline \multirow{5}{*}{ Internet efficacy } & CE1 & 0.832 & \multirow{5}{*}{0.922} & \multirow{5}{*}{0.942} & \multirow{5}{*}{0.764} & \multirow{5}{*}{0.874} \\
\hline & CE2 & 0.881 & & & & \\
\hline & CE3 & 0.891 & & & & \\
\hline & CE4 & 0.907 & & & & \\
\hline & CE5 & 0.857 & & & & \\
\hline \multirow{3}{*}{$\begin{array}{l}\text { Communication } \\
\text { self-efficacy (CSE) }\end{array}$} & $\mathrm{CS} 1$ & 0.923 & \multirow{3}{*}{0.921} & \multirow{3}{*}{0.950} & \multirow{3}{*}{0.863} & \multirow{3}{*}{0.929} \\
\hline & CS2 & 0.938 & & & & \\
\hline & $\mathrm{CS} 3$ & 0.927 & & & & \\
\hline \multirow{4}{*}{ Computer Anxiety } & CA1 & 0.837 & \multirow{4}{*}{0.841} & \multirow{4}{*}{0.894} & \multirow{4}{*}{0.678} & \multirow{4}{*}{0.824} \\
\hline & CA2 & 0.815 & & & & \\
\hline & CA3 & 0.875 & & & & \\
\hline & CA4 & 0.763 & & & & \\
\hline \multirow{6}{*}{$\begin{array}{l}\text { Institutional } \\
\text { support (IS) }\end{array}$} & IS1 & 0.807 & \multirow{6}{*}{0.908} & \multirow{6}{*}{0.929} & \multirow{6}{*}{0.686} & \multirow{6}{*}{0.828} \\
\hline & IS2 & 0.845 & & & & \\
\hline & IS3 & 0.820 & & & & \\
\hline & IS4 & 0.831 & & & & \\
\hline & IS5 & 0.842 & & & & \\
\hline & IS6 & 0.824 & & & & \\
\hline \multirow{5}{*}{ Student readiness } & SR1 & 0.774 & \multirow{5}{*}{0.856} & \multirow{5}{*}{0.898} & \multirow{5}{*}{0.640} & \multirow{5}{*}{0.800} \\
\hline & SR2 & 0.636 & & & & \\
\hline & SR3 & 0.875 & & & & \\
\hline & SR4 & 0.863 & & & & \\
\hline & SR5 & 0.829 & & & & \\
\hline \multirow{6}{*}{$\begin{array}{l}\text { Evaluation of e- } \\
\text { learning } \\
\text { experience }\end{array}$} & ET1 & 0.851 & \multirow{6}{*}{0.918} & \multirow{6}{*}{0.936} & \multirow{6}{*}{0.709} & \multirow{6}{*}{0.842} \\
\hline & ET2 & 0.869 & & & & \\
\hline & ET3 & 0.780 & & & & \\
\hline & ET4 & 0.877 & & & & \\
\hline & ET5 & 0.835 & & & & \\
\hline & ET6 & 0.838 & & & & \\
\hline
\end{tabular}

Note: AVE: Average Variance Extracted: Square Root AVE, CA: Cronbach's Alpha, CR: Composite Reliability

\subsection{Structural Model}

It is revealed from figure (2) that Internet efficacy is positively affecting the student's readiness to elearning $(\beta \mathrm{IE} \rightarrow \mathrm{SR}=0.49$ and $\mathrm{P}<.01) \quad(\mathrm{H} 1$ is supported), communication self-efficacy is positively affecting the students readiness to e-learning $(\beta \mathrm{CSE} \rightarrow \mathrm{SR}=0.20$ and $\mathrm{P}<.01)(\mathrm{H} 2$ is supported $)$. Both Computer $(\beta C A \rightarrow S R=-0.01$ and and $\mathrm{P}>0.05)$ and Institutional support $(\beta I S \rightarrow S R=-0.01$ and $P>.05)$ have no significant effect on readiness and therefore the third and fourth hypotheses are not supported.

Fig. 2 collinearity variance inflation factor $=2.397$; Tenenhaus goodness of fit $=0.595$; Sympson's paradox ratio $=0.800 ; \mathrm{R} 2$ contribution ratio $=0.996$; statistical suppression ratio $=1.000$; and nonlinear bivariate causality direction ratio $=0.800$.

To sum up, the four constructs in the model (Internet efficacy, communication self-efficacy, Computer Anxiety, Institutional support) explain $43 \%$ of variance in student's readiness. In turn, student's readiness to e-learning has a significant effect on evaluation of e-learning experience in tourism education ( $\beta$ SR $\rightarrow \mathrm{ET}=0.74$ and $\mathrm{P}<0.1)(\mathrm{H} 5)$ is supported, student's readiness explains $55 \%$ of variance in evaluation of e-learning experience in tourism education 
The Structural Research Model

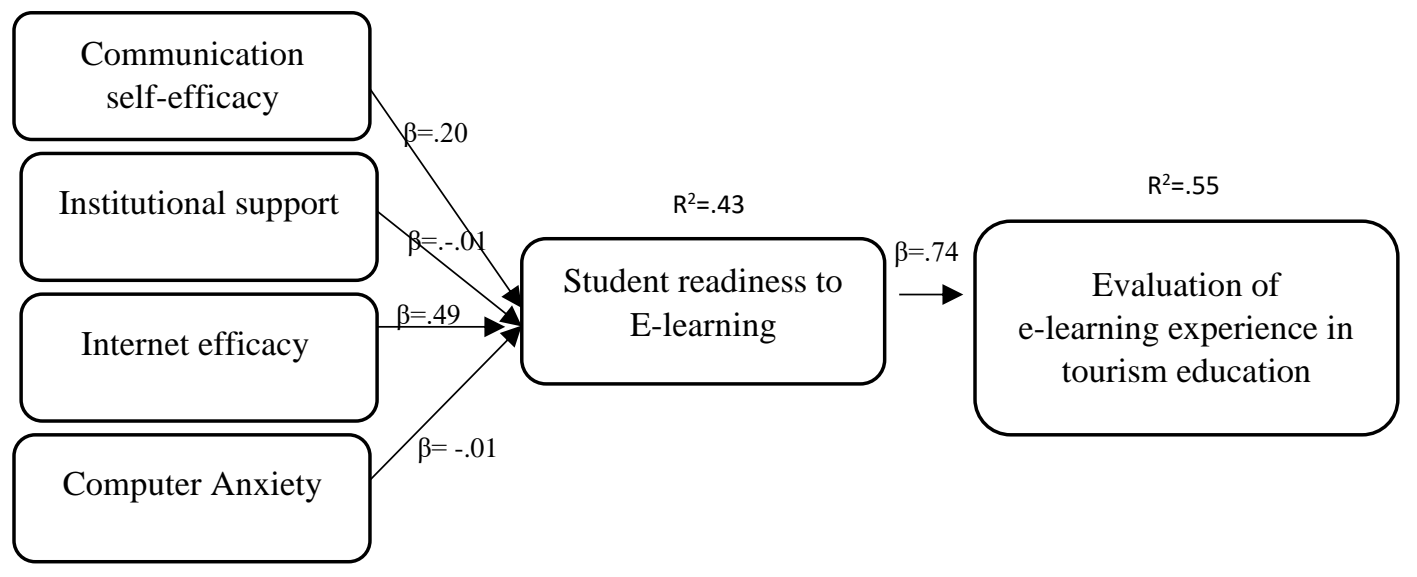

\section{Discussion of Finding}

Critically analyzing the revealed findings, it is clear that internet self-efficacy is the highest factor affecting student readiness to e-learning. This is in line with previous studies by Hung, (2016) and Rafique, et al., (2020) who found that ISE is considered an important dimension that affects the extent of students' readiness for e-learning. This revealed that students can deal with various computer programs such as Microsoft Office and Adobe Acrobat, which is agreed with (Hung, 2010). In addition, Students can work in a group for studies online. This is in line with Rafique, et al., (2020). Then, it is found that students can perform homework and online educational activities (participate in classroom forums - download assignments.etc). This finding is consistent a previous with the study of Hung, (2010). Students can interact quickly and efficiently with e-learning techniques. This finding is consistent with previous studies specifying the importance of internet self-efficacy such as Hung, (2016); and Hung, (2016 a). Next, Elearning platforms are easy to use. This is in line with an extant study explaining the advantages of using platforms (Khan, et al., 2020).

One of the most important factors in research contribution to student e-learning readiness is communication self-efficacy (CSE). Students clarified that they are confident when utilizing e-learning tools to efficiently connect with others. This finding is in line with the study of Hung, (2016). In addition, they thought that they are confident in using e-learning tools. This finding is consistent a previous with the study of Shen, et al., (2013).

As for the computer anxiety, the present study has not revealed a significant effect of computer anxiety on student readiness to e-learning. As a result of the COVID-19 outbreak, lecturers and undergraduates has find themselves adopted on e-learning (Mishra, et al.,
2020). Hence, Egyptian universities has been worked on transferring traditional educational curricula's (Hammad \& Zohry, 2020), to internet by using online portals and Video conferencing platforms such as Zoom, Microsoft Teams, Google meet, Google Classroom, Skype and Webex Blackboard (Mukhtar, et al., 2020, Shahzad, et al., 2020). Besides, using social media applications like Whatsapp, Facebook, Twitter, Instagram. Thus, these ICT applications have reduced the anxiety as they are available on smartphones and laptops and are also characterized by flexibility and ease using which enable tourism students to achieve better educational results (Mishra, et al., 2020). In addition, according to Sam, et al., (2005) the higher level of computer skills undergraduate students has, the lower computer anxiety.

Another important factor in the present study is institutional support which has not revealed a significant effect on student readiness to e-learning. This is due to some of the negatives that hinder the smooth implementation of e-learning in some tourism and hotel faculties, such as lack of awareness about the importance of e-learning, and insufficient preparedness, (e.g., the absence of e-learning units, and inadequate training and workshops provided to faculty members and students about e-learning and its various applications, and poor Internet service in some places (Hammad \& Zohry, 2020; Fox, et al., 2020). Furthermore, Mukhtar, et al., (2020) explained that faculty members and students are not able to perform practical work.

\section{Conclusion and Recommendations}

The present study has investigated the effect of selfefficacy in internet and communication, Computer Anxiety, and Institutional support on the readiness of tourism and hotels students in the Egyptian 
universities, subsequently, evaluating the experience of using e-learning tools in tourism education during COVID-19, it is found that the Egyptian government offered supplementary electronic services to the educational process. E-learning has become very substantial where educational institutions have faced significant challenges of keeping the learning process running smoothly while ensuring benefit. The present study contributes to theory as it is the first study, to the author' knowledge so far, exploring the e- learning readiness and evaluating the experience of using elearning in Egyptian tourism and hotels faculties. The study adds to the knowledge in e-learning in tourism education. In addition, the present study contributes to practice. It is useful for policymakers who wish to do their best to improve E- learning process. Where the education institutions could improve its policies, strategies and systems in terms of E- learning. Through, the need for a unified educational platform, commensurate with the characteristics of the professional and practical tourism sector and meet the changes occurring in. In addition to supporting the basic ICT infrastructure and periodically training technical support staff to use ICT tools effectively

In the light of the theoretical framework of the study and through the findings of the empirical results, some recommendations can be developed:

- Focusing on recognizing the different learning styles of struggling students

- Simplifying educational content to suit students' individual differences and their skills in using technology and educational materials

- Continuously supporting institutions of higher education for the infrastructure of universities

- Providing training workshops on a regular basis for students and lecturers on how to use modern technological tools

- Providing software and electronic devices at reasonable prices for use at home for all students.

\section{References}

Alanazy, S. M., (2018). Factors Affecting Faculty Attitude for Adopting Online Learning at Aljouf University, Saudi Arabia. Journal of Education and Learning, 7(1), 154162.

Aldhafeeri, F. M. \& Khan, B. H., (2016). Teachers' and students' views on e-learning readiness in Kuwait's secondary public schools.. Journal of Educational Technology Systems, 45(2), 202-235.

Ali, W., (2020). Online and remote learning in higher education institutes: A necessity in light of COVID-19 pandemic. Higher Education Studies, 10(3), 16-25.
Alqahtani, A. Y. \& Rajkhan, A. A., (2020). E-learning critical success factors during the covid-19 pandemic: A comprehensive analysis of e-learning managerial perspectives. Education Sciences, 10(9), 216.

Bertea, P., (2009). Measuring Students'attitude Towards ELearning. A Case Study. In Conference proceedings of elearning and Software for Education, else(01), 417424.

Demir, Ö. \&. Y. H., (2015). The Exploration of models regarding e-learning readiness: Reference model suggestions. International Journal of Progressive Education, 11(1), 173- 194.

Dinh, L. P. \& Nguyen, T. T., (2020). Pandemic, social distancing, and social work education: Students' satisfaction with online education in Vietnam.. Social Work Education, 39(8), 1074-1083.

Falola, H. O., Adeniji, A. A., Adeyeye, J. O. \& Igbinnoba, E. E. \&. A. T. O., (2020) . Measuring institutional support strategies and faculty job effectiveness. Heliyon, 6(3), e03461.

Forson, I. K. \& Vuopala, E., (2019). Online learning readiness: perspective of students enrolled in distance education in Ghana.". The Online Journal of Distance Education and e-Learning , 7(4), 277-29.

Fox, K., Bryant, G., Lin, N. \& Srinivasa, N., (2020). Time for Class-COVID-Part 1: A National Survey of Faculty during COVID-19. Tyton Partners and Every Learner Everywhere .

Galy, E. D. C. \& Johnson, J., (2011). The effect of using elearning tools in online and campus-based classrooms on student performance. Journal of Information Technology Education: Research, 10(1), pp. 209-230.

Gurley, L. E., (2018). Educators' Preparation to Teach, Perceived Teaching Presence, and Perceived Teaching Presence Behaviors in Blended and Online Learning Environments.. Online learning, 22(2), 197-220.

Hammad, A. \& Zohry, M. A. E.-F., (2020). Obstacles Hindering the Implementation of E-learning in the Faculties of Tourism and Hotels in Egyptian Public Universities. Journal of Association of Arab Universities for Tourism and Hospitality, 18(2), 76-95.

Hung, M.-L., (2016). Online learning readiness: Its relations to college students' changes over time, and willingness to enroll in future courses. International Journal of Technology and Human Interaction (IJTHI), 12(1), 5162.

Hung, M.-L., (2016 a). Teacher readiness for online learning: Scale development and teacher perceptions.". Computers \& Education ,94, 120-133.

Hung, M.-L. \& Chou, C., (2015). Students' perceptions of instructors' roles in blended and online learning environments: A comparative study, Computers \& Education, 81, 315-325.

Hung, M.-L., Chou, C., Chen, C.-H. \& Own, Z.-Y. , (2010). Learner readiness for online learning: Scale development and student perceptions. Computers \& Education, 55(3), 1080-1090. 
Ismaili, Y., (2020). Evaluation of students' attitude toward distance learning during the pandemic (Covid-19): a case study of ELTE university. On the Horizon, Volume ahead-of-print.

Khan, M. A., Nabi, M. K., Khojah, M. \& Tahir, M., (2020). "Students' Perception towards E-Learning during COVID-19 Pandemic in India: An Empirical Study. Sustainability, 13(1), 1-14.

Linjawi, A. I. \& Agou, S., (2020). E-learning readiness among dental students and faculty members Pre-COVID-19 pandemic. Journal of Microscopy and Ultrastructure, 8(4), pp. 168-174.

Masrom, M., Zainon, O. \& Rahiman, R., (2008). Critical success in e-learning: An examination of technological and institutional support factors. International Journal of Cyber Society and Education, 1(2), 131-142.

Masrom, M., Zainon, O. \& Rahiman, R., (2008). Critical success in e-learning: An examination of technological and institutional support factors. International Journal of Cyber Society and Education, 1(2), 131-142.

Ministry of Higher Education \& Scientific Research, (2020). [Online] Available at: http://portal.mohesr.gov.eg

Mishra, L., Gupta, T. \& \& Shree, A., (2020). Online teachinglearning in higher education during lockdown period of COVID-19 pandemic. International Journal of Educational Research Open, 1(100012).

Mukhtar, K., Javed, K., Arooj, M. \& Sethi, A., (2020). Advantages, Limitations and Recommendations for online learning during COVID-19 pandemic era. Pakistan journal of medical sciences, 36(COVID19S4).

Oyedotun, T. D., (2020). Sudden change of pedagogy in education driven by COVID-19: Perspectives and evaluation from a developing country. Research in Globalization 2, 100029.

Ozturk, D. S., Ozturk, F. \& Rasit, O. Z. E. N., (2018). The Relationship between Prospective Teachers' Readiness and Satisfactions About Internet-Based Distance Education. Turkish Online Journal of Distance Education, 19(1), 147-162.

Philipsen, B. T. J. R. N. P. V. S. \&. Z. C., (2019). Improving teacher professional development for online and blended learning: A systematic meta-aggregative review. Educational Technology Research and Development, 67(5), 1145-1174.
Rafique, G. M., Mahmood, K., Warraich, N. F. \& Rehman, S. U., (2020). "Readiness for Online Learning during COVID-19 pandemic: A survey of Pakistani LIS students.. The Journal of Academic Librarianship, 47(3), 102346.

Rapanta, C. et al., (2020). Online university teaching during and after the Covid-19 crisis: Refocusing teacher presence and learning activity. Postdigital Science and Education, 2(3), 923-945.

Sam, H. K., Othman, A. E. A. \& Nordin, Z. S., (2005). Computer self-efficacy, computer anxiety, and attitudes toward the Internet: A study among undergraduates in Unimas. Journal of Educational Technology \& Society, 8(4), 205-219.

Shahzad, A. et al., (2020). Effects of COVID-19 in Elearning on higher education institution students: the group comparison between male and female. Quality \& quantity, 1-22.

Shahzad, A. et al., (2020). Effects of COVID-19 in Elearning on higher education institution students: the group comparison between male and female. Quality \& quantity, 55(3), 805-826.

Shen, D., Cho, M.-H., Tsai, C.-L. \& Marra, R., (2013). Unpacking online learning experiences: Online learning self-efficacy and learning satisfaction. The Internet and Higher Education, 19, 10-17.

Smart, K. L. \& Cappel, J. J., (2006). Students' perceptions of online learning: A comparative study. Journal of Information Technology Education: Research, 5(1), 201-219.

Tuntirojanawong, S., (2013). Students' Readiness for ELearning: A Case Study of Sukhothai Thammathirat Open University, Thailand. Journal of Learning in Higher Education, 9(1), 59-66..

Widodo, S. F. A., Wibowo, Y. E. \& Wagiran, W., (2020). Online learning readiness during the Covid-19 pandemic. In Journal of Physics: Conference Series, 1700(1), 012033.

Zhang, W., Wang, Y., Yang, L. \& Wang, C., (2020). Suspending classes without stopping learning: China's education emergency management policy in the COVID-19 outbreak, 55-61. 